\title{
Efficient In Vitro Propagation by Ex Vitro Rooting Methods of Artemisia absinthium L., an Ethnobotanically Important Plant
}

\author{
Mahipal S. Shekhawat and M. Manokari \\ Biotechnology Laboratory, Department of Plant Science, MGGAC, Mahe, Pondicherry 673311, India \\ Correspondence should be addressed to Mahipal S. Shekhawat; smahipal3@gmail.com
}

Received 2 August 2015; Accepted 30 September 2015

Academic Editor: Olaf-Georg Issinger

Copyright ( 2015 M. S. Shekhawat and M. Manokari. This is an open access article distributed under the Creative Commons Attribution License, which permits unrestricted use, distribution, and reproduction in any medium, provided the original work is properly cited.

\begin{abstract}
Artemisia absinthium is an important medicinal plant. Owing to the increasing anthropogenic activities and demand from the pharmaceutical industry, this plant species is overexploited; thereby this endangered its genetic stock in the wild. Therefore, it is urgently needed to develop nonconventional methods for conservation of $A$. absinthium. Nodal segments obtained from the field grown 2-month-old plants were used as explants. Murashige and Skoog (MS) medium containing 0.5 mg/L 6-benzylaminopurine (BAP) and $0.25 \mathrm{mg} / \mathrm{L}$ kinetin $(\mathrm{Kn})$ were reported to be optimum for induction of shoots $(6.0 \pm 0.52$ shoots per explant). The shoots were multiplied by repeated transfer of original explants and by subculturing of in vitro raised shoots on MS medium augmented with $1.0 \mathrm{mg} / \mathrm{L}$ each of BAP and $\mathrm{Kn}$ and $0.1 \mathrm{mg} / \mathrm{L} \alpha$-naphthaleneacetic acid (NAA). All in vitro regenerated shoots (100\%) were rooted ( $4.4 \pm 0.35$ roots) on one-fourth strength MS medium supplemented with $2.0 \mathrm{mg} / \mathrm{L}$ indole- 3 butyric acid (IBA). Cent percentage shoots rooted ex vitro on sterile Soilrite under the greenhouse conditions when the shoots were treated with $200 \mathrm{mg} / \mathrm{L}$ of IBA for 5 min. Plantlets rooted in vitro and ex vitro were acclimatized successfully in the greenhouse and exhibited $87 \%$ and $95 \%$ survival rate.
\end{abstract}

\section{Introduction}

Artemisia absinthium L. (Asteraceae family) is an aromatic, perennial herb, commonly known as wormwood, afsantine, or wermut. It is native to warm Mediterranean countries and distributed in Europe and Asia [1]. With a very long tradition, the whole plant is used in the treatment of fevers, malaria, gastritis, menstrual pains, jaundice, scabies, and tetanus and as brain tonic [2]. A. absinthium is used in food industry/confectionaries in the preparation of aperitives, bitters, and spirits and as flavoring agent for preparation of beverage absinthe [3]. This plant is nearly threatened in the wild [4] and reported as endangered due to its highly specific pharmacological profile [5].

Thujone, absinthe, trans-sabinyl acetate, chrysanthenyl acetate, and sesquiterpenes like $\alpha$-bisabolol, $\beta$-curcumin, and spathulenol are the major volatile compounds extracted from $A$. absinthium, with huge medicinal and commercial significance $[6,7]$. The volatile compound yields essential oil with number of pharmacological activities such as hepatoprotective, cognitive effects and neuroprotective, antioxidant [8], antidiabetic, antimalarial, antimicrobial, antiparasitic, and antipyretic activities $[9,10]$.

The whole plant contains artemisinin as a secondary metabolite along with terpenes, limonene, myrcene, $\alpha$ - and $\beta$-thujone, sesquiterpene, caryophyllene [11], sabinyl acetate, and chrysanthenyl acetate [12]. It also contains camphor, p-cymene, isoledene, absinthin, absinthic acid, anabsinthin, astabsin, and artametin [13]. The concentration and quality of phytochemicals increased at the time of flowering [14]. The presence of flavonoids, caffeic acids, chlorogenic acid, syringic acid, salicylic acid, vanillic acid, carotenoids, coumarins, homoditerpene peroxides, and thiophene also fuelled its phytochemistry $[15,16]$.

A. absinthium can be propagated naturally by seeds and vegetative cuttings. White rust, powdery and downy mildews, and rusts of leaf and stem are the common diseases of this plant. Vegetative propagation causes the carry-over 
of disease-causing microorganisms from one generation to the next [17]. In vitro culture/micropropagation has been recognized as an important tool in ex situ conservation and reintroduction trials $[18,19]$. Ex vitro rooting helps in reduction of cost of production, energy, and resources and increases chance of survival of plantlets during hardening and field transfer [20]. Consequently, the present investigation is concerned to establish axenic cultures of the endangered herb $A$. absinthium and to optimize the in vitro conditions for complete plantlets regeneration for its conservation. This is the first report of micropropagation of $A$. absinthium using ex vitro rooting method which supported the survival chances of plants under natural conditions.

\section{Material and Methods}

2.1. Plant Material and Disinfection of Explants. Nodal segments with axillary bud were collected from Coromandel Coast (Puducherry, Cuddalore, Nagapattinam, and Karaikal districts) of South India during March, 2013, to January, 2014. The juvenile nodal shoots from 60-day-old plants were collected and washed with running tap water continuously for ten minutes. The explants are immersed in $70 \%$ ethanol for 3-5 min and rinsed with sterile distilled water for three times. The systemic disinfection was done with $0.1 \%$ aqueous solution of Bavistin (Systemic fungicide, BASF India, Ltd.) for $5 \mathrm{~min}$. Finally the explants were disinfected by $0.1 \%$ mercuric chloride for 4-5 min. While handling mercuric chloride, care has been taken and standard safety procedures were followed during the study.

2.2. Culture Media and Conditions. Standard MS basal medium [21] with $0.8 \%$ agar was used for culture establishment. The medium was fortified with additives which included $50 \mathrm{mg} / \mathrm{L}$ ascorbic acid, $25 \mathrm{mg} / \mathrm{L}$ each of adenine sulphate, L-arginine, and citric acid. To optimize the perfect growth regulators for successful micropropagation of $A$. absinthium, MS media were supplemented with different concentrations of cytokinins (BAP and $\mathrm{Kn}$ ) and auxins (IAA, IBA, NAA, and naphthoxyacetic acid; NOA). The gel strength $(\mathrm{pH})$ of culture medium was adjusted to $5.80 \pm 0.02$ and steamsterilized by autoclave at 15 psi pressure at $121^{\circ} \mathrm{C}$ for $15 \mathrm{~min}$. The cultures were incubated at $25 \pm 2^{\circ} \mathrm{C}, 40-50 \mu \mathrm{mol}^{-2} \mathrm{~s}^{-1}$ Photon Flux Density (PFD) light intensity for 12 to $12 \mathrm{~h}$ dark to light photoperiods provided by cool white fluorescent 40 watt lamps (Philips, India) with $60 \%$ relative humidity (RH).

2.3. Induction and Shoot Proliferation. To optimize the use of plant growth regulators on nodal bud break, different concentrations of cytokinins (BAP and $\mathrm{Kn}, 0.25$ to $1.5 \mathrm{mg} / \mathrm{L}$ ) alone or in combination have been used. The regenerated shoots with nodal mother explants were dissected into segments and transferred to various concentrations of cytokinins (BAP and $\mathrm{Kn} 0.25$ to $2.0 \mathrm{mg} / \mathrm{L}$ ) alone or in combination with optimized concentration of NAA $(0.1 \mathrm{mg} / \mathrm{L})$ for shoots proliferation. To evaluate the effect of auxins on shoot multiplication and elongation, different concentrations of NAA have been incorporated on shoot proliferating medium. Cultures with bud break were multiplied by subsequent transfer of shoot clumps with mother explants to fresh medium containing additives at 25-day intervals.

2.4. In Vitro Rooting of Micropropagated Shoots. The regenerated shoots with approximate length $(3-4 \mathrm{~cm})$ were separated and transferred to half and one-fourth strength MS medium supplemented with various concentrations $(0.5$ to $4.0 \mathrm{mg} / \mathrm{L})$ of rooting hormones (IAA, IBA, and NOA) to induce roots in vitro. The cultures were incubated under diffused light for 2 weeks.

2.5. Ex Vitro Rooting. For ex vitro rooting, in vitro regenerated shoots $(4-5 \mathrm{~cm}$ in length) were excised and treated with various concentrations of root inducing auxins (IAA, IBA, and NOA) at different concentrations (50 to $500 \mathrm{mg} / \mathrm{L}$ ) for $5 \mathrm{~min}$. The auxin treated shoots were transferred to a mixture of horticultural grade perlite with Irish peat moss and exfoliated vermiculite (Soilrite, Kel Perlite, Bangalore, India), moistened with one-fourth strength of aqueous MS basal salt solution, and maintained in the greenhouse, where high humidity ( $\mathrm{RH} 80-90 \%)$ and low temperature $\left(25 \pm 2^{\circ} \mathrm{C}\right)$ were maintained.

2.6. Hardening and Acclimatization. In vitro and ex vitro rooted plantlets were hardened in the greenhouse, where micropropagated plantlets were maintained at partial natural and controlled environment. The plantlets were exposed partly to open greenhouse environment when the roots are initiated over a period of 20 days. The rooted plantlets were gradually shifted to perforated nursery polybags containing organic manure, red soil, and garden soil $(1: 1: 1)$ and placed at low humidity $(60-70 \% \mathrm{RH})$ and high temperature $\left(30 \pm 2^{\circ} \mathrm{C}\right)$ for 40 days. Finally fully hardened plantlets were transferred to the field and the survival rate was recorded.

2.7. Collection of Data and Statistical Analysis. The experiments in the present study were conducted with ten replicates per treatment and repeated three times. Data for different concentrations and combinations of cytokinins and auxins with MS basal medium (response of explants, shoot regeneration, shoot length, number of roots, and root length) were recorded after 30 days of cultures. Shoot induction capacities on the multiplication medium were assessed by recording the percentage of successful shoot regeneration, the multiplication rate corresponding to the number of new shoots produced, and the length of shoot growth at each transfer. Thus obtained data were subjected to analyze statistically using SPSS 16.0 software (IBM Corporation SPSS, North America). The results are expressed as mean $\pm \mathrm{SD}$ of experiments and the significance of difference among the means was calculated using Duncan's Multiple Range Test at $p<0.05$ level. 
TABLE 1: Effect of cytokinins (BAP and Kn) concentration on bud breaking from nodal explants of A. absinthium.

\begin{tabular}{lcccc}
\hline $\begin{array}{l}\text { Plant growth regulators (mg/L) } \\
\text { Kn }\end{array}$ & BAP & Bud breaking response (\%) & $\begin{array}{c}\text { Number of shoots/explants } \\
(\text { mean } \pm \text { SD) }\end{array}$ & $\begin{array}{c}\text { Shoot length (cm) } \\
(\mathrm{mean} \pm \mathrm{SD})\end{array}$ \\
\hline 0 & - & 0 & $0.0 \pm 0.00^{\mathrm{a}}$ & $0.00 \pm 0.00^{\mathrm{a}}$ \\
0.25 & - & 68 & $2.9 \pm 1.03^{\mathrm{d}}$ & $1.43 \pm 1.38^{\mathrm{f}}$ \\
0.5 & - & 53 & $2.3 \pm 0.28^{\mathrm{c}}$ & $1.17 \pm 0.96^{\mathrm{c}}$ \\
1.0 & - & 50 & $2.0 \pm 0.46^{\mathrm{b}}$ & $1.24 \pm 0.52^{\mathrm{c}}$ \\
1.5 & - & 46 & $1.5 \pm 0.21^{\mathrm{b}}$ & $1.30 \pm 0.86^{\mathrm{d}}$ \\
- & 0.25 & 72 & $3.2 \pm 0.94^{\mathrm{d}}$ & $2.26 \pm 0.73^{\mathrm{g}}$ \\
- & 0.5 & 89 & $4.5 \pm 0.22^{\mathrm{g}}$ & $2.54 \pm 0.67^{\mathrm{i}}$ \\
- & 1.0 & 82 & $4.0 \pm 0.54^{\mathrm{f}}$ & $1.37 \pm 0.26^{\mathrm{e}}$ \\
- & 1.5 & 78 & $3.7 \pm 0.82^{\mathrm{e}}$ & $1.02 \pm 0.39^{\mathrm{b}}$ \\
0.25 & 0.25 & 84 & $5.3 \pm 0.76^{\mathrm{i}}$ & $2.95 \pm 0.64^{\mathrm{j}}$ \\
0.25 & 0.5 & 100 & $6.0 \pm 0.52^{\mathrm{j}}$ & $3.25 \pm 0.42^{\mathrm{k}}$ \\
0.25 & 1.0 & 93 & $5.0 \pm 0.36^{\mathrm{h}}$ & $2.58 \pm 0.26^{\mathrm{i}}$ \\
0.25 & 1.5 & 86 & $4.6 \pm 0.29^{\mathrm{h}}$ & $2.36 \pm 0.44^{\mathrm{h}}$ \\
\hline
\end{tabular}

Note: each value represents the mean \pm SD of ten replicates. Mean values \pm SD followed by the same superscripts within columns are not significantly different at $p<.05$ level by Duncan's Multiple Range Test (DMRT).

\section{Results and Discussion}

3.1. Induction of Shoots. Nodal segments collected from 2month-old plant sources were regenerated quickly in all concentrations of cytokinins tested, but promising results were obtained on MS medium incorporated with BAP at optimized level. The juvenile explants took shorter time with cent percentage response in shoot induction experiments. Out of different concentrations, MS medium augmented with $0.5 \mathrm{mg} / \mathrm{L} \mathrm{BAP}+0.25 \mathrm{mg} / \mathrm{L} \mathrm{Kn}$ was reported to be most effective for induction of shoots in vitro. On this concentration maximum $(6.0 \pm 0.52)$ shoots with length $(3.25 \pm 0.42 \mathrm{~cm})$ were recorded (Table 1$)$. Multiple and healthy shoots were produced right after first subculture on this medium combination (Figures 1(a) and 1(b)). The results of in vitro regeneration on Acacia auriculiformis [22] and Turnera ulmifolia [23] also support the combined effects of BAP and $\mathrm{Kn}$ in shoot induction. The MS medium devoid of growth regulators did not show any regeneration capacity of axillary buds in the present study. Tahir et al. [24] reported shoot induction in $A$. absinthium on the combination of $\mathrm{GA}_{3}$ and BAP. Cytokinins (BAP and $\mathrm{Kn}$ ) were proved responsible for cell elongation and division which induce shoots from the explants.

3.2. Shoot Proliferation. The shoots regenerated from mother explants were transferred to fresh MS medium containing BAP, Kn, and NAA for multiplication of shoots. Formation of multiple shoots was recorded when the shoots with mother explants were subcultured to fresh medium with $1.0 \mathrm{mg} / \mathrm{L}$ each of BAP and $\mathrm{Kn}+0.1 \mathrm{mg} / \mathrm{L}$ NAA. Maximum number $(43.7 \pm 0.39$ shoots per explant per culture vessel) and length
$(7.4 \pm 0.26 \mathrm{~cm})$ of shoots were recorded on this medium combination (Figures 1(c) and 1(d), Table 2).

The number of shoots produced in this study is considerably higher in comparison to the previous reports on the same plant species [24-26]. The application of NAA in shoot proliferation was reported in Ceropegia bulbosa [27] and Caralluma edulis [28]. The combined use of BAP and NAA also enhanced proliferation of shoots in Artemisia annua [29]. The addition of NAA with cytokinins plays significant role in multiple shoot production [26]. The higher concentration of BAP and $\mathrm{Kn}$ than NAA in the culture medium could induce shoot organogenesis.

3.3. In Vitro Rooting of Elongated Shoots. Out of three auxins tested, IBA was reported to be best for both in vitro and ex vitro rooting of in vitro regenerated shoots. Shoots were rooted with maximum $4.4 \pm 0.35$ roots and highest average root length $(4.53 \pm 0.38 \mathrm{~cm})$ on one-fourth strength MS medium containing $2.0 \mathrm{mg} / \mathrm{L}$ IBA within 21 days (Figure 1(e)). In comparison to IBA, IAA and NOA were detected less effective for root induction (Table 3 ). The effective role of IBA in in vitro root induction has been reported in many plants, such as Vitex negundo [30], Momordica dioica, Morinda coreia, M. citrifolia [31-33], Arnebia hispidissima [34], and Cleome gynandra [35]. Earlier findings also support our results of in vitro rooting in this plant as recorded by Kour et al. [26] but they obtained highest response with half strength MS medium supplemented with $0.5 \mathrm{mg} / \mathrm{L} \mathrm{IBA.}$

3.4. Ex Vitro Rooting of Micropropagated Plantlets. In this study, in vitro rejuvenated shoots were subjected to ex vitro 


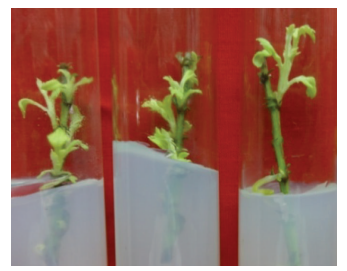

(a)

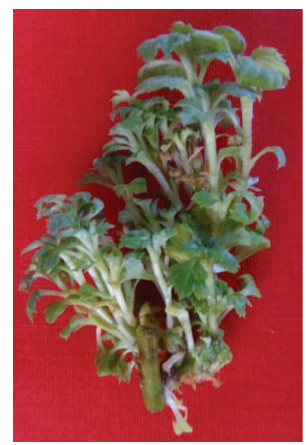

(c)

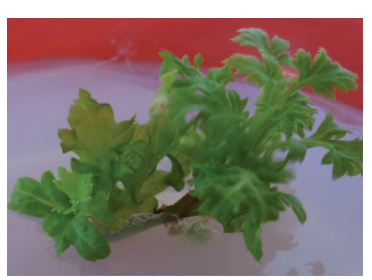

(b)

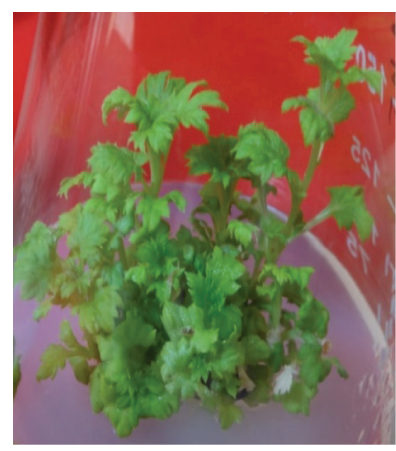

(d)

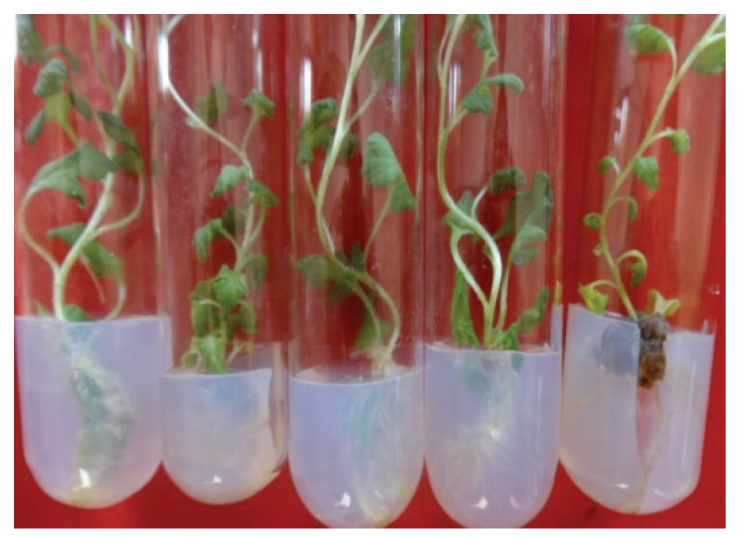

(e)

FIGURE 1: (a) Induction of shoots from the nodal meristems of the explants. (b) Shoots with explant after 4 weeks. (c) and (d) Multiplication of shoots in vitro on MS medium with BAP, Kn, and NAA. (e) In vitro root induction from the cut end of the shoots with IBA.

rooting method. In recent years, this technique is given more emphasis than in vitro rooting technique by many tissue culturists during the micropropagation of plants at commercial scale because it reduces the steps in micropropagation, cost, labor resources, and time. In addition, ex vitro rooted plantlets were easy to harden as compared to in vitro rooted plants with higher percentage of survival frequency and quick adaptation to natural environment $[36,37]$.

The individually excised shoots were rooted ex vitro when treated with $200 \mathrm{mg} / \mathrm{L}$ of IBA (Table 4). In comparison to in vitro rooting, higher percent of shoots were rooted by this method. Maximum $7.3 \pm 0.40$ roots with average $6.84 \pm 0.24 \mathrm{~cm}$ length were achieved within 3-4 weeks (Figure 2(a)). Indole3 acetic acid and NOA were less effective than IBA for ex vitro root induction in the greenhouse conditions. Similar results were also obtained in Arnebia hispidissima [38], Ceropegia bulbosa [27], and Caralluma edulis [28].
3.5. Hardening of Plantlets. The in vitro and ex vitro rooted plantlets were examined to study the survival response during hardening stage. The rooted plantlets were acclimatized successfully in the greenhouse (Figures 2(b), 2(c), and 2(d)). In comparison to in vitro rooted plantlets, the survival percentage of ex vitro rooted plantlets was significantly higher (Figure 2(e)). About $87 \%$ and $95 \%$ plantlets were survived which were rooted via in vitro and ex vitro rooting methods, respectively. According to Yan et al. [20] the probable reason of higher rate of survival of ex vitro rooted plantlets is due to the presence of more number of lateral roots (like natural root system), root hairs, and higher root length.

\section{Conclusion}

We have utilized juvenile nodal explants for regeneration of shoots of A. absinthium with conservation priority status. In 
TABLE 2: Shoot amplification on MS medium supplemented with different concentrations of cytokinins + 0.1 mg/L NAA.

\begin{tabular}{lcccc}
\hline \multicolumn{3}{c}{ Plant growth regulators $(\mathrm{mg} / \mathrm{L})$} & Number of shoots $($ mean \pm SD $)$ & Shoot length $(\mathrm{cm})(\mathrm{mean} \pm \mathrm{SD})$ \\
Kn & BAP & NAA & $00.0 \pm 0.00^{\mathrm{a}}$ & $0.0 \pm 0.00^{\mathrm{a}}$ \\
0.00 & 0.00 & 0.00 & $18.6 \pm 1.03^{\mathrm{b}}$ & $2.6 \pm 1.38^{\mathrm{b}}$ \\
0.25 & - & 0.1 & $23.0 \pm 0.28^{\mathrm{b}}$ & $3.9 \pm 0.96^{\mathrm{cd}}$ \\
0.50 & - & 0.1 & $32.7 \pm 0.46^{\mathrm{d}}$ & $4.4 \pm 0.52^{\mathrm{d}}$ \\
1.00 & - & 0.1 & $28.4 \pm 0.21^{\mathrm{c}}$ & $4.1 \pm 0.86^{\mathrm{cd}}$ \\
1.50 & - & 0.1 & $25.1 \pm 0.20^{\mathrm{b}}$ & $3.7 \pm 0.50^{\mathrm{c}}$ \\
2.00 & - & 0.1 & $25.4 \pm 0.94^{\mathrm{b}}$ & $2.8 \pm 0.73^{\mathrm{b}}$ \\
- & 0.1 & $33.6 \pm 0.22^{\mathrm{d}}$ & $4.3 \pm 0.67^{\mathrm{c}}$ \\
- & 0.50 & 0.1 & $38.0 \pm 0.54^{\mathrm{f}}$ & $5.6 \pm 0.26^{\mathrm{e}}$ \\
- & 1.00 & 0.1 & $35.9 \pm 0.82^{\mathrm{e}}$ & $5.0 \pm 0.39^{\mathrm{d}}$ \\
- & 1.50 & 0.1 & $30.7 \pm 0.29^{\mathrm{c}}$ & $4.5 \pm 0.42^{\mathrm{c}}$ \\
\hline 0.25 & 2.00 & 0.1 & $36.1 \pm 0.76^{\mathrm{b}}$ & $4.1 \pm 0.64^{\mathrm{b}}$ \\
0.50 & 0.25 & 0.1 & $41.0 \pm 0.52^{\mathrm{d}}$ & $5.6 \pm 0.42^{\mathrm{c}}$ \\
1.00 & 0.50 & 0.1 & $43.7 \pm 0.39^{\mathrm{e}}$ & $7.4 \pm 0.26^{\mathrm{d}}$ \\
1.50 & 1.00 & 0.1 & $40.5 \pm 0.22^{\mathrm{d}}$ & $6.0 \pm 0.44^{\mathrm{c}}$ \\
\hline
\end{tabular}

Note: each value represents the mean \pm SD of ten replicates. Mean values \pm SD followed by the same superscripts within columns are not significantly different at $p<.05$ level by Duncan's Multiple Range Test (DMRT).

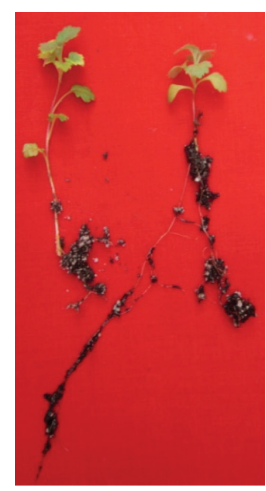

(a)

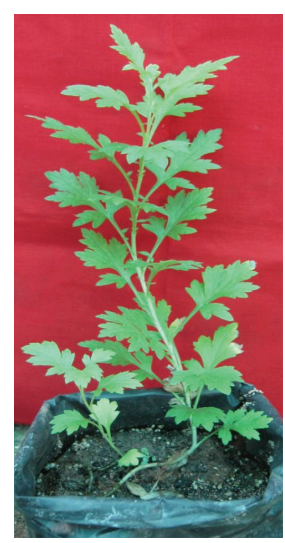

(d)

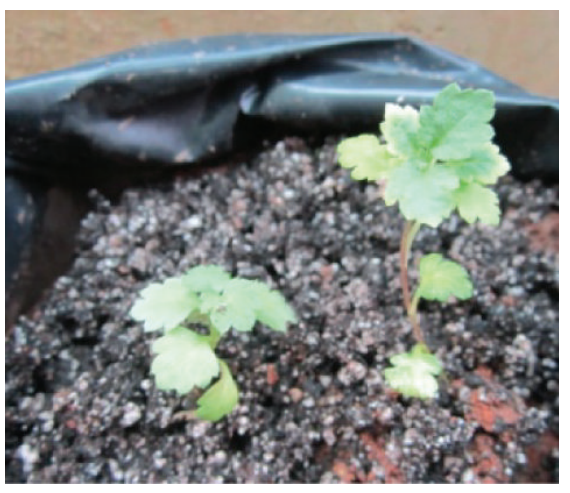

(b)

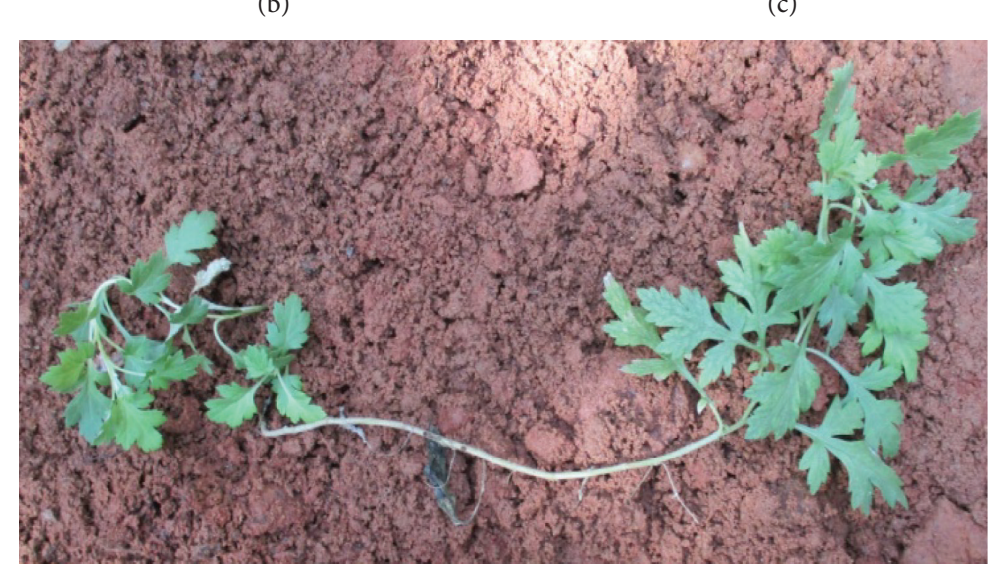

(e)

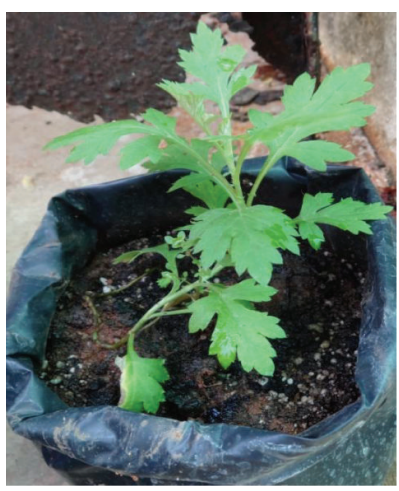

(c)

Figure 2: (a) Ex vitro rooting to the in vitro regenerated shoots in Soilrite. (b), (c), and (d) Different stages in the hardening of the plantlets in the greenhouse. (e) Field transferred plant of A. absinthium. 
TABLE 3: Effect of auxins on in vitro root induction of A. absinthium shoots on $1 / 4$ th MS medium.

\begin{tabular}{|c|c|c|}
\hline $\begin{array}{l}\text { Auxins concentration } \\
(\mathrm{mg} / \mathrm{L})\end{array}$ & $\begin{array}{l}\text { Number of roots/shoots } \\
(\text { mean } \pm \text { SD })\end{array}$ & $\begin{array}{l}\text { Root length }(\mathrm{cm}) \\
(\text { mean } \pm \mathrm{SD})\end{array}$ \\
\hline \multicolumn{3}{|l|}{ IAA } \\
\hline 0.5 & $0.0 \pm 0.00^{\mathrm{a}}$ & $0.00 \pm 0.00^{\mathrm{a}}$ \\
\hline 1.0 & $0.0 \pm 0.00^{\mathrm{a}}$ & $0.00 \pm 0.00^{\mathrm{a}}$ \\
\hline 1.5 & $0.7 \pm 0.35^{\mathrm{bc}}$ & $1.00 \pm 0.12^{\mathrm{b}}$ \\
\hline 2.0 & $1.2 \pm 0.22^{\mathrm{c}}$ & $1.35 \pm 0.03^{c}$ \\
\hline 3.0 & $1.0 \pm 0.30^{\mathrm{bc}}$ & $1.70 \pm 0.24^{\mathrm{d}}$ \\
\hline 4.0 & $0.6 \pm 0.32^{b}$ & $1.32 \pm 0.40^{c}$ \\
\hline \multicolumn{3}{|l|}{ IBA } \\
\hline 0.5 & $2.2 \pm 0.44^{\mathrm{a}}$ & $2.37 \pm 0.25^{\mathrm{b}}$ \\
\hline 1.0 & $3.5 \pm 0.30^{\mathrm{b}}$ & $3.12 \pm 0.22^{c}$ \\
\hline 1.5 & $4.0 \pm 0.41^{\mathrm{cd}}$ & $3.78 \pm 0.29^{\mathrm{de}}$ \\
\hline 2.0 & $4.4 \pm 0.35^{\mathrm{d}}$ & $4.53 \pm 0.38^{\mathrm{f}}$ \\
\hline 3.0 & $3.6 \pm 0.27^{\mathrm{b}}$ & $3.95 \pm 0.40^{\mathrm{e}}$ \\
\hline 4.0 & $2.4 \pm 0.41^{\mathrm{a}}$ & $3.50 \pm 0.39^{\mathrm{d}}$ \\
\hline \multicolumn{3}{|l|}{$\mathrm{NOA}$} \\
\hline 0.5 & $0.5 \pm 0.36^{\mathrm{b}}$ & $1.41 \pm 0.19^{c}$ \\
\hline 1.0 & $0.9 \pm 0.20^{c}$ & $1.96 \pm 0.24^{\mathrm{d}}$ \\
\hline 1.5 & $1.4 \pm 0.47^{\mathrm{d}}$ & $2.55 \pm 0.40^{\mathrm{e}}$ \\
\hline 2.0 & $2.0 \pm 0.62^{f}$ & $2.79 \pm 0.39^{\mathrm{e}}$ \\
\hline 3.0 & $1.7 \pm 0.42^{\mathrm{e}}$ & $1.63 \pm 0.28^{c}$ \\
\hline 4.0 & $1.0 \pm 0.39^{c}$ & $1.04 \pm 0.42^{\mathrm{b}}$ \\
\hline
\end{tabular}

Note: each value represents the mean \pm SD of ten replicates. Mean values \pm SD followed by the same superscripts within columns are not significantly different at $p<.05$ level by Duncan's Multiple Range Test (DMRT).

this study an efficient micropropagation protocol has been developed using axillary meristems. The ex vitro rooting approach helped to exempt the drawbacks of time, labor, cost, and resources which increased the survival percentage of plantlets during hardening and field transfer.

\section{Disclosure}

The present research work has not involved any human participants and/or animal.

\section{Conflict of Interests}

The authors report that there is no conflict of interests regarding the publication of this paper.
TABLE 4: Effect of various roots inducing auxins on ex vitro root induction of in vitro regenerated shoots.

Auxins concentration Number of roots/shoots Root length $(\mathrm{cm})$ $(\mathrm{mg} / \mathrm{L})$

$($ mean \pm SD $)$

$($ mean $\pm \mathrm{SD})$

Control

0

$0.0 \pm 0.00^{\mathrm{a}}$

$0.00 \pm 0.00^{\mathrm{a}}$

IAA

50

100

200

300

400

500

$2.4 \pm 0.51^{\mathrm{b}}$

$0.89 \pm 0.33^{b}$

0

00

$2.7 \pm 0.63^{\mathrm{b}}$

$1.08 \pm 0.49^{c}$

$4.3 \pm 0.47^{d}$

$1.53 \pm 0.31^{\mathrm{d}}$

00

$4.4 \pm 0.72^{\mathrm{d}}$

$1.94 \pm 0.20^{\mathrm{f}}$

$4.0 \pm 0.44^{\mathrm{d}}$

$2.05 \pm 0.46^{\mathrm{f}}$

IBA

$$
50
$$

100

200

300

400

500

NOA

$$
50
$$

100

200

300

400

$3.3 \pm 0.39^{c}$

$1.74 \pm 0.43^{\mathrm{e}}$

500

$\begin{array}{ll}4.2 \pm 0.93^{\mathrm{b}} & 4.64 \pm 0.51^{\mathrm{b}} \\ 5.6 \pm 0.59^{\mathrm{cd}} & 5.08 \pm 0.39^{\mathrm{c}} \\ 7.3 \pm 0.40^{\mathrm{e}} & 6.84 \pm 0.24^{\mathrm{f}} \\ 6.0 \pm 0.45^{\mathrm{d}} & 5.95 \pm 0.19^{\mathrm{e}} \\ 5.8 \pm 0.49^{\mathrm{cd}} & 5.42 \pm 0.17^{\mathrm{d}} \\ 5.4 \pm 0.33^{\mathrm{c}} & 5.00 \pm 0.28^{\mathrm{c}}\end{array}$

Note: treatment duration: $5 \mathrm{~min}$. Each value represents the mean $\pm \mathrm{SD}$ of ten replicates. Mean values \pm SD followed by the same superscripts within columns are not significantly different at $p<.05$ level by Duncan's Multiple Range Test (DMRT).

\section{Acknowledgment}

The authors are grateful to the Department of Science, Technology and Environment, Government of Puducherry, for providing financial support as grant-in-aid scheme.

\section{References}

[1] C. W. Wright, Artemisia, Taylor \& Francis, New York, NY, USA, 2002.

[2] R. A. Qureshi, M. A. Ghufran, K. N. Sultana, M. Ashraf, and A. G. Khan, "Ethnobotanical studies of medicinal plants of gilgit district and surrounding areas," Ethnobotany Research and Applications, vol. 5, pp. 115-122, 2007. 
[3] D. K. Mishra, S. N. Naik, V. K. Srivatsava, and R. Prasad, "Effect of Matricaria chamomilla flowers on chemical composition of essential oil," Journal of Medicinal and Aromatic Plant Sciences, vol. 21, pp. 1020-1025, 1999.

[4] G. Colling, "Red list of the vascular plants of Luxembourg," Ferrantia, vol. 42, pp. 16-18, 2005.

[5] F. Bhat, D. M. Mahajan, M. R. G. Sayyed, and A. Bhat, "Ethno-medicinal survey of north Kashmir Himalaya-a case study of Lolab vally (J \& K), India," Ecology, Environment and Conservation, vol. 20, no. 1, pp. 59-71, 2014.

[6] J. H. Cano and G. Volpato, "Herbal mixtures in the traditional medicine of Eastern Cuba," Journal of Ethnopharmacology, vol. 90, no. 2-3, pp. 293-316, 2004.

[7] F. S. Sharopov, V. A. Sulaimonova, and W. N. Setzer, "Composition of the essential oil of Artemisia absinthium from Tajikistan," Records of Natural Products, vol. 6, no. 2, pp. 127-134, 2012.

[8] L. Riahi, H. Chograni, M. Elferchichi, Y. Zaouali, N. Zoghlami, and A. Mliki, "Variations in Tunisian wormwood essential oil profiles and phenolic contents between leaves and flowers and their effects on antioxidant activities," Industrial Crops and Products, vol. 46, pp. 290-296, 2013.

[9] A. M. Stanciuc, A. Gaspar, L. Moldovan, C. Saviuc, M. Popa, and L. Măruțescu, "In vitro antimicrobial activity of Romanian medicinal plants hydroalcoholic extracts on planktonic and adhered cells," Roumanian Archives of Microbiology and Immunology, vol. 70, no. 1, pp. 11-14, 2011.

[10] K. Yildiz, M. Başalan, O. Duru, and S. Gökpinar, "Antiparasitic efficiency of Artemisia absinthium on Toxocara cati in naturally infected cats," Türkiye Parazitoloji Dergisi, vol. 35, no. 1, pp. 1014, 2011.

[11] A. O. Tucker, M. J. Maciarello, and G. Sturtz, "Essential oils of Artemisia 'Powis Castle' and its putative parents, A. absinthium and A. arborescens," Journal of Essential Oil Research, vol. 5, no. 3, pp. 239-242, 1993.

[12] F. P. Chilava, A. P. Lidlle, and G. Doglia, "Chemotaxonomy of wormwood (Artemisia absinthium L.)," Zeitschrift für Lebensmittel-Untersuchung und -Forschung, vol. 176, pp. 363366, 1983.

[13] L. Kostadinovic, J. Levic, T. G. Coghill, and L. Ruzicic, "Anticoccidian effects of the Artemisia absinthium L. extracts in broiler chickens," Archivia Zootechnica, vol. 15, no. 2, pp. 69-77, 2012.

[14] A. Orav, A. Raal, E. Arak, M. Muurisepp, and T. Kailas, "Composition of the essential of the essential oil of Artemisia absinthium L. of different geographical origin," Proceedings of the Estonian Academy of Sciences. Chemistry, vol. 55, no. 3, pp. 155-165, 2006.

[15] A. Rezaeinodehi and S. Khangholi, "Chemical composition of the essential oil of Artemisia absinthium growing wild in Iran," Pakistan Journal of Biological Sciences, vol. 11, no. 6, pp. 946-949, 2008.

[16] A. Nezhadali and M. Parsa, "Study of the volatile compounds in Artemisia absinthium from Iran using HP/SPME/GC/MS," Advances in Applied Science Research, vol. 1, no. 3, pp. 174-179, 2010.

[17] V. Z. Acedo, "Meristem culture and micropropagation of cassava," Journal of Root Crops, vol. 28, pp. 1-7, 2002.

[18] J. K. Rowntree and M. M. Ramsay, "Ex situ conservation of bryophytes: progress and potential of a pilot project," Boletim da Sociedade Broteriana, vol. 26-27, pp. 17-22, 2005.
[19] B. M. Reed, V. Sarasan, M. Kane, E. Bunn, and V. C. Pence, "Biodiversity conservation and conservation biotechnology tools," In Vitro Cellular and Developmental Biology - Plant, vol. 47, no. 1, pp. 1-4, 2011.

[20] H. Yan, C. Liang, L. Yang, and Y. Li, "In vitro and ex vitro rooting of Siratia grosvenorii, a traditional medicinal plant," Acta Physiologiae Plantarum, vol. 32, no. 1, pp. 115-120, 2010.

[21] T. Murashige and F. Skoog, "A revised medium for rapid growth and bio assays with tobacco tissue cultures," Physiologia Plantarum, vol. 15, no. 3, pp. 473-497, 1962.

[22] H. Ismail, N. A. Shukor, A. M. Yusoff et al., "In vitro shoot induction of Acacia auriculiformis from juvenile and mature sources," E3 Journal of Biotechnology and Pharmaceutical Research, vol. 3, no. 5, pp. 88-93, 2012.

[23] M. S. Shekhawat, N. Kannan, M. Manokari, and M. P. Ramanujam, "An efficient micropropagation protocol for highfrequency plantlet regeneration from liquid culture of nodal tissues in a medicinal plant, Turnera ulmifolia L.," Journal of Sustainable Forestry, vol. 33, no. 4, pp. 327-336, 2014.

[24] S. M. Tahir, S. Usman, M. D. Katung, and M. F. Ishiyaku, "Micro propagation of wormwood (Artemisia annua L.) using leaf primordial," Science World Journal, vol. 8, no. 1, pp. 1-7, 2013.

[25] S. Nin, E. Morosi, S. Schiff, and A. Bennici, "Callus cultures of Artemisia absinthium L.: initiation, growth optimization and organogenesis," Plant Cell, Tissue and Organ Culture, vol. 45, no. 1, pp. 67-72, 1996.

[26] B. Kour, G. Kour, S. Kaul, and M. K. Dhar, "In vitro mass multiplication and assessment of genetic stability of in vitro raised Artemisia absinthium L. plants using ISSR and SSAP molecular markers," Advances in Botany, vol. 2014, Article ID 727020, 7 pages, 2014.

[27] M. Phulwaria, N. S. Shekhawat, J. S. Rathore, and R. P. Singh, "An efficient in vitro regeneration and ex vitro rooting of Ceropegia bulbosa Roxb.-A threatened and pharmaceutical important plant of Indian Thar Desert," Industrial Crops and Products, vol. 42, no. 1, pp. 25-29, 2013.

[28] A. K. Patel, M. Phulwaria, M. K. Rai, A. K. Gupta, S. Shekhawat, and N. S. Shekhawat, "In vitro propagation and ex vitro rooting of Caralluma edulis (Edgew.) Benth. \& Hook. F.: an endemic and endangered edible plant species of the Thar Desert," Scientia Horticultuae, vol. 165, pp. 175-180, 2014.

[29] S. Geng, Y. H. Chun, and L. Gufeng, "Flowering of Artemisia annua L. test tube plantlets and Artemisinin production with shoot cluster induced from flower organs explants," Chinese Journal of Applied and Environmental Biology, vol. 7, pp. 201206, 2001.

[30] M. S. Rathore and N. S. Shekhawat, "Micropropagation of Vitex negundo through in vitro bud proliferation," Agricultural Science Research Journal, vol. 1, no. 8, pp. 191-198, 2011.

[31] M. S. Shekhawat, N. S. Shekhawat, Harish, K. Ram, M. Phulwaria, and A. K. Gupta, "High frequency plantlet regeneration from nodal segment culture of female Momordica dioica (Roxb.)," Journal of Crop Science and Biotechnology, vol. 14, no. 2, pp. 133-137, 2011.

[32] M. S. Shekhawat, N. Kannan, and M. Manokari, "In vitro propagation of traditional medicinal and dye yielding plant Morinda coreia Buch.-Ham," South African Journal of Botany, vol. 100, pp. 43-50, 2015.

[33] M. S. Shekhawat, N. Kannan, M. Manokari, and C. Ravindran, "Enhanced micropropagation protocol of Morinda citrifolia 
L. through nodal explants," Journal of Applied Research on Medicinal and Aromatic Plants, 2015.

[34] M. Phulwaria and N. S. Shekhawat, "An efficient in vitro shoot regeneration from immature inflorescence and ex vitro rooting of Arnebia hispidissima (Lehm). DC.-a red dye (Alkannin) yielding plant," Physiology and Molecular Biology of Plants, vol. 19, no. 3, pp. 435-441, 2013.

[35] N. S. Rathore, N. Rathore, and N. S. Shekhawat, "In vitro propagation and micromorphological studies of Cleome gynandra: a C4 model plant closely related to Arabidopsis thaliana," Acta Physiologiae Plantarum, vol. 35, no. 9, pp. 2691-2698, 2013.

[36] P. K. Pati, S. P. Rath, M. Sharma, A. Sood, and P. S. Ahuja, "In vitro propagation of rose-a review," Biotechnology Advances, vol. 24, no. 1, pp. 94-114, 2006.

[37] D. Annapurna and T. S. Rathore, "Direct adventitious shoot induction and plant regeneration of Embelia ribes Burm F," Plant Cell, Tissue and Organ Culture, vol. 101, no. 3, pp. 269-277, 2010.

[38] M. S. Shekhawat and N. S. Shekhawat, "Micropropagation of Arnebia hispidissima (Lehm). DC. and production of alkannin from callus and cell suspension culture," Acta Physiologiae Plantarum, vol. 33, no. 4, pp. 1445-1450, 2011. 

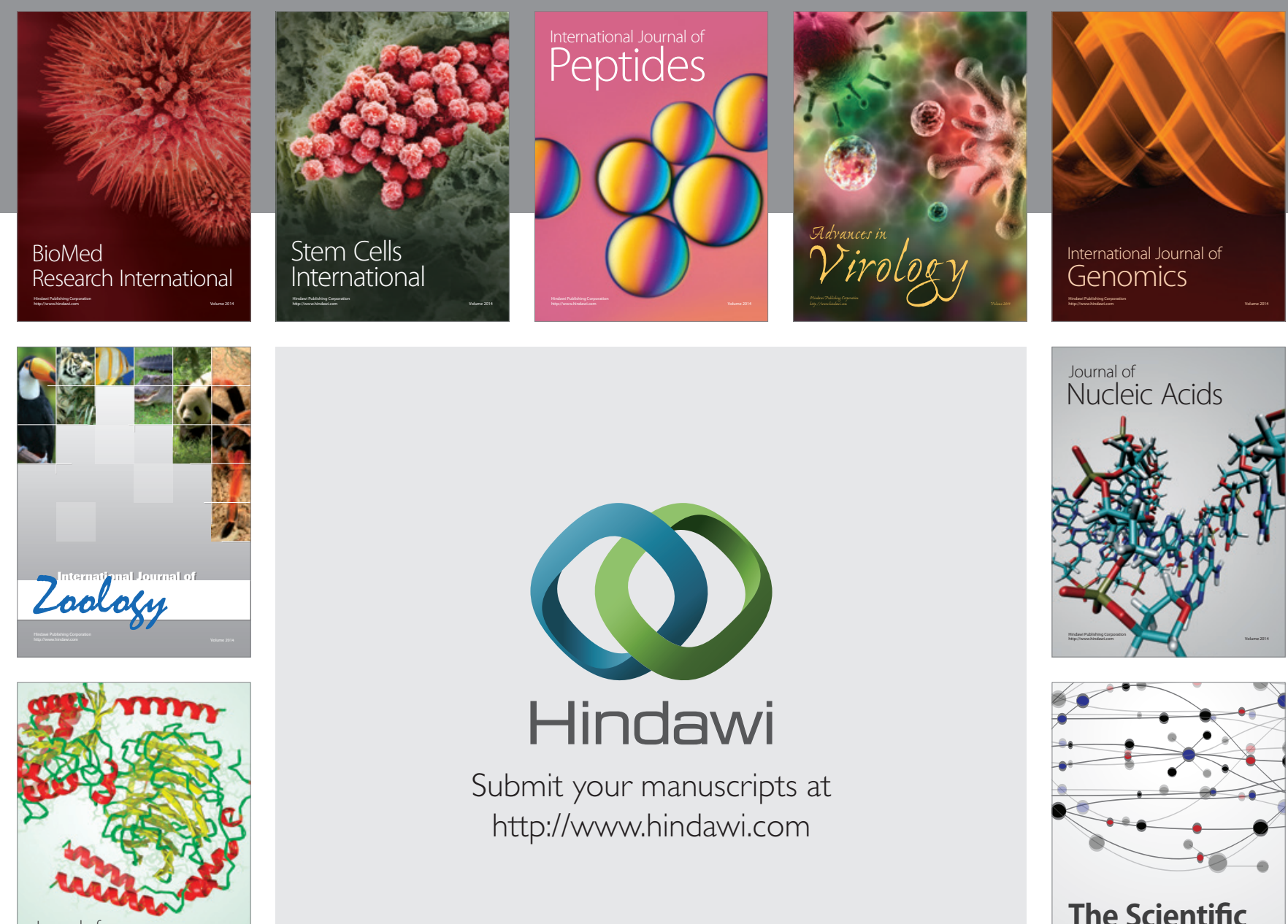

Submit your manuscripts at

http://www.hindawi.com

Journal of
Signal Transduction
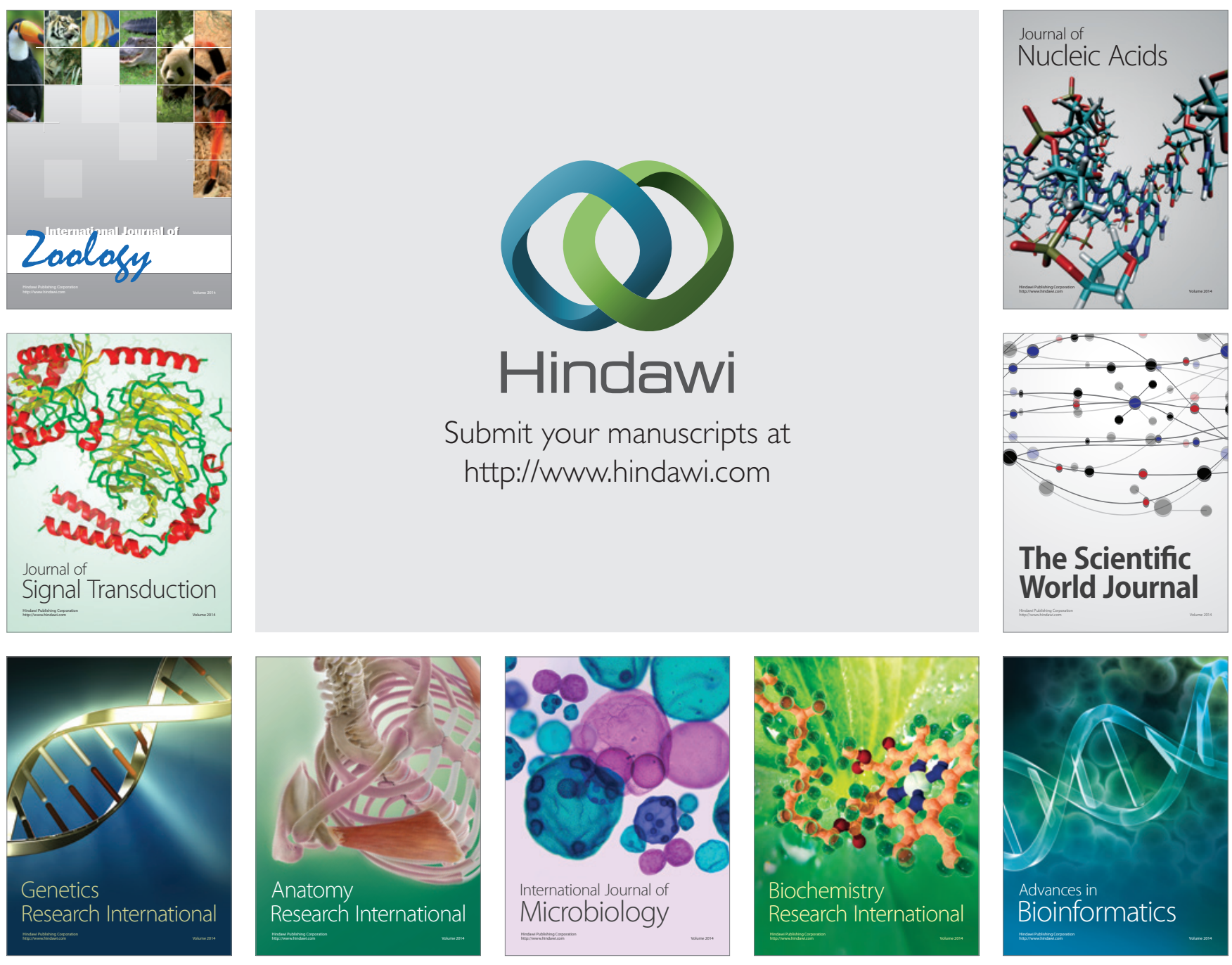

The Scientific World Journal
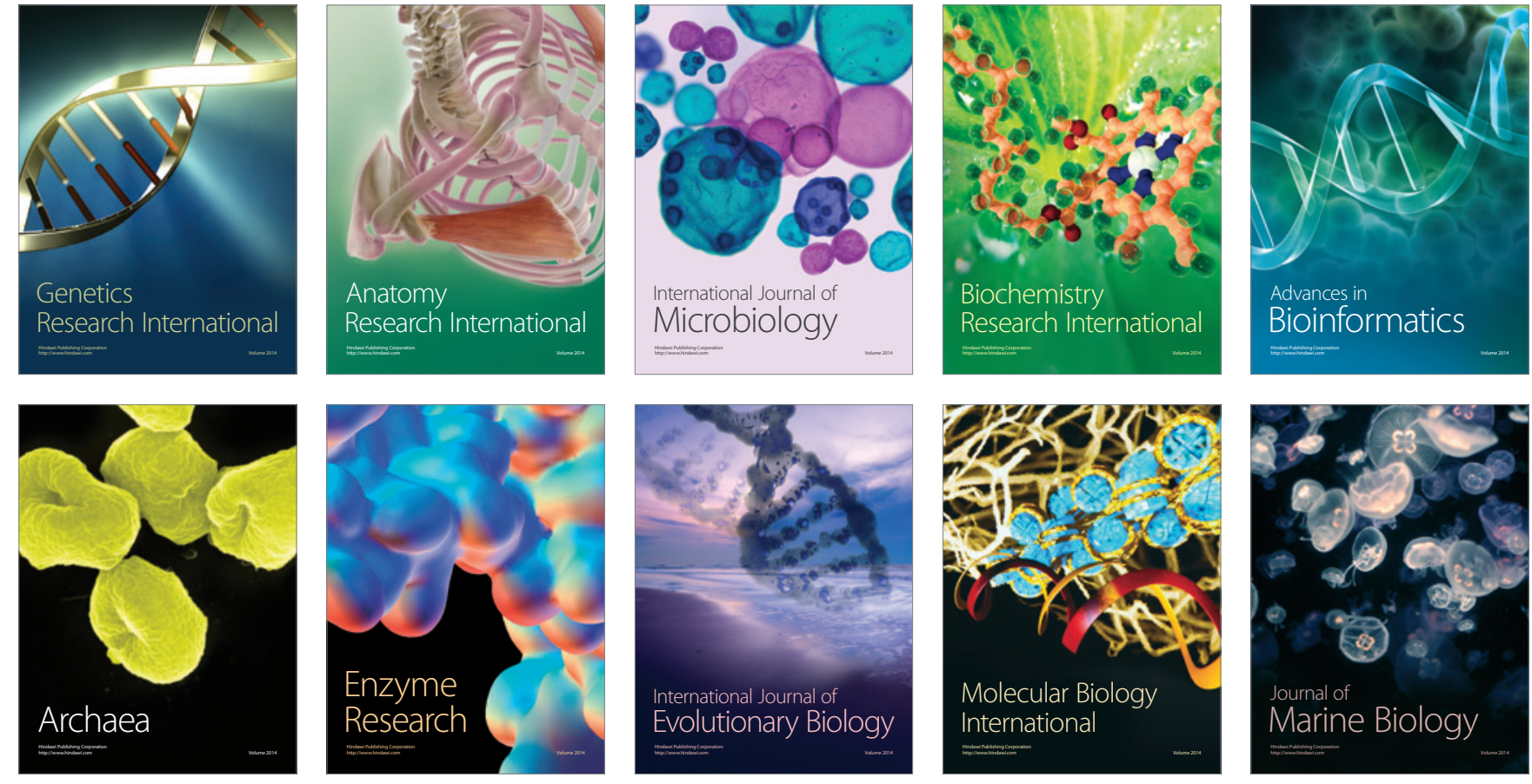